\title{
Spectrum of very early breast cancer in a setting without organised screening
}

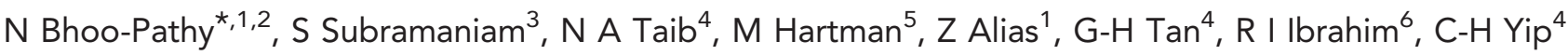 \\ and $\mathrm{H}$ M Verkooijen ${ }^{5}$
}

\begin{abstract}
${ }^{1}$ Department of Social and Preventive Medicine, Julius Centre University of Malaya, Faculty of Medicine, University of Malaya, 50603 Lembah Pantai, Kuala Lumpur, Malaysia; ${ }^{2}$ Julius Center for Health Sciences and Primary Care, University Medical Center Utrecht, 3508 GA Utrecht, The Netherlands; ${ }^{3}$ National Clinical Research Centre, Hospital Kuala Lumpur, Level 3, Dermatology Block, Jalan Pahang, 50586 Kuala Lumpur, Malaysia; ${ }^{4}$ Department of Surgery, Faculty of Medicine, University of Malaya, 50603 Lembah Pantai, Kuala Lumpur, Malaysia; ${ }^{5}$ Saw Swee Hock School of Public Health, National University of Singapore, MD3, 16 Medical Drive, Singapore 117597, Singapore and ${ }^{6}$ Faculty of Science and Technology, Islamic Science University of Malaysia (USIM), 71800 Nilai, Negeri Sembilan, Malaysia
\end{abstract}

Background: Within a setting without organised breast cancer screening, the characteristics and survival of very early breast cancer were determined.

Methods: All 4930 women diagnosed with breast cancer in University Malaya Medical Center, Malaysia from 1993 to 2011 were included. Factors associated with very early presentation (stage I) at diagnosis were identified. Tumour characteristics, management patterns, and survival of very early breast cancer were described, and where appropriate, compared with other settings.

Results: Proportion of women presenting with stage I breast cancer significantly increased from $15.2 \%$ to $25.2 \%$ over two decades. Factors associated with very early presentation were Chinese ethnicity, positive family history of breast cancer, and recent period of diagnosis. Within stage I breast cancers, median tumour size at presentation was $1.5 \mathrm{~cm}$. A majority of stage I breast cancer patients received mastectomy, which was associated with older age, Chinese ethnicity, postmenopausal status, and larger tumours. Chemotherapy was administered in $36 \%$ of patients. Five-year age-adjusted relative survival for women with stage I breast cancer was $99.1 \%$ (95\% Cl: 97.6-99.6\%).

Conclusions: The proportion of women presenting with very early breast cancer in this setting without organised screening is increasing. These women seem to survive just as well as their counterparts from affluent settings.

While breast cancer incidence rates have stabilised or even decreased in affluent western countries, the incidence of breast cancer in most Asian countries continues to escalate over the past few decades (Wang and Cao, 1996; Ravdin et al, 2007; Porter, 2008; Fontenoy et al, 2010). Furthermore, a substantial proportion of Asian patients with breast cancer are diagnosed at advanced stages compared with their western counterparts rendering survival rates to suboptimal levels in this part of the world (Anderson et al, 2011).
Early detection is associated with better survival probabilities, where the 5 and 10-year survival rates for women diagnosed with stage 0 or I breast cancer range between $90 \%$ and 100\% (Owen et al, 2013; Ries and Esner, 2013). The two cornerstones of early detection are awareness of the disease, and both opportunistic and population-based screening. While population-based screening mammography is implemented in many affluent western countries, it is argued as not being cost-effective in most of Asia (Woo et al, 2007; Okonkwo et al, 2008; Kang et al, 2013) and had been offered

*Correspondence: Dr N Bhoo-Pathy; E-mail: ovenjjay@gmail.com

Received 5 December 2013; revised 7 March 2014; accepted 15 March 2014; published online 15 April 2014

(c) 2014 Cancer Research UK. All rights reserved 0007-0920/14 
only in high-income countries including Japan since 1987, Korea since 1999, and Singapore since 2003 (Kwong et al, 2008; Lim et al, 2010).

Given that Asia has seen rapid socio-economic development over recent times, it is conceivable that awareness of (breast) cancer in the population has increased, leading to more women presenting at earlier stages of breast cancer despite the absence of organised breast cancer screening programs. Malaysia is a middle-income country in South East Asia, which comprises three major ethnic groups, that is, Malays, Chinese, and Indians. It does not implement population-based mammography screening programme, but adopts opportunistic screening where mammography is targeted and offered to high-risk women. Clinical breast examination (CBE) by trained health professionals and self-breast examination (SBE) are also widely advocated, but as a measure to increase breast cancer awareness among women at risk rather than as a screening method.

We sought to determine the trends in presentation of very early breast cancer (stage I), and the associated factors in a Malaysia setting. Tumour characteristics, management patterns, and survival of very early breast cancer were described, and where appropriate, compared with other settings.

\section{MATERIALS AND METHODS}

Patients from the University Malaya Medical Centre (UMMC) Breast Cancer Registry were included in the study. The UMMC is an academic tertiary hospital situated in the city of Kuala Lumpur, Malaysia and caters to a predominantly middle class urban population. Since 1993, all patients with newly diagnosed breast cancer have been entered into a hospital-based breast cancer registry, and data on demographics, tumour profile, and treatment have been collected prospectively (Bhoo Pathy et al, 2011). This registry has received the approval of UMMC's Ethical Review Committee.

Staging of primary breast cancer in UMMC consisted of physical examination, blood tests, chest X-ray, and liver ultrasound. Diagnostic work-up for the presence of distant metastasis was performed in symptomatic patients, and those with clinical stage III disease by means of computed tomography scan of thorax, abdomen $+1-$ pelvis, as well as bone scan. Testing for Human Epidermal Growth Factor Receptor 2 (HER2) status was only routinely done after 2005 .

The current study comprises 4930 women who were newly diagnosed with invasive breast cancer between 1993 and 2011. Women with missing information on stage at diagnosis were excluded $(n=307 ; 6 \%)$.

Study variables. All breast cancers were restaged according to the 7th edition of TNM American Joint Committee on Cancer (AJCC) system. Very early presentation was defined as presentation with AJCC stage I breast cancer at initial diagnosis, whereas more advanced presentation comprise AJCC stage II, stage III, or stage IV breast cancers. Data on patient's socio-demographic characteristics included age at diagnosis, ethnicity (Malay, Chinese, Indian, and other races), marital status (unmarried and married), parity (nulliparous, 1-2 children, and 3 or more children), and year of diagnosis (1993-1997, 1998-2002, 2003-2007, and 2008-2011). Data on risk factors include menopausal status (premenopausal and postmenopausal), and family history of breast cancer in firstor second-degree relative (present and absent). As information on education and occupation was only sparsely available, these variables were not included in this study. Variables on tumour characteristics included pathologically determined tumour size (available as continuous values in $\mathrm{cm}$ ), oestrogen receptor (ER) status (positive when $>10 \%$ of tumour cells stained positive during immunohistochemical (IHC) testing, negative), tumour grade (Scarff-Bloom-Richardson classification; grade 1, grade 2 and grade 3), lymphovascular invasion (LVI) (present and absent), and HER2 status (positive when IHC testing $=3+$, negative when IHC testing $=1+$ or $2+$ ).

Loco-regional treatment data included type of surgery (no surgery, mastectomy, breast conserving surgery (BCS)) and radiotherapy (yes and no). Systemic treatment data comprised chemotherapy (yes and no), type of chemotherapy (regime), and endocrine therapy (yes and no). While details on targeted therapy were not available for a majority of the patients, the use of such therapies was very low during the study period.

Follow-up and outcome assessment. Patients were monitored via scheduled appointments in the specialist breast clinic. Vital status was verified through direct linkage with the National Registration Department in Malaysia. Follow-up time was calculated from the date of diagnosis, to the date of death, or end of follow-up in February 2012.

Statistical analysis. Patient characteristics were compared between those presenting very early, and at later stages, in an initial univariable logistic regression analysis using very early presentation as the outcome. Variables with $P$-values of $<0.20$ were entered into a stepwise backward logistic regression to determine factors that were independently and significantly associated with very early presentation.

The National Institutes of Health (NIH) Consensus Development Conference recommendations were used as a reference to assess the treatment patterns of very early breast cancers in this middle-income setting. In 1990, the NIH Consensus Development Conference on treatment of patients with early breast cancer had recommended BCS for the majority of women with stage I or stage II disease (National Institutes of Health, 1990). The NIH Consensus Development Conference also recommends administration of adjuvant chemotherapy for node-negative breast tumours when tumour size is greater than $1 \mathrm{~cm}$, irrespective of hormone receptor status (Eifel et al, 2001). Therefore, chemotherapy administration rate in this subgroup of women was assessed. In instances when the treatment patterns differ with the recommendations, stepwise backward logistic regression analysis was used to determine the predictors of treatment to better understand factors influencing such treatment decisions.

As causes of death for a large proportion of patients were not available, relative survival rate (RSR) following diagnosis of stage I breast cancer was estimated using the Ederer II method for expected survival (Coleman et al, 2008). Relative survival is the ratio of all-cause survival observed in patients with very early breast cancer in the current study, to the survival that would have been expected had they been subjected only to the mortality rates of the general population (background mortality). It can be interpreted as net survival attributable to (very early breast) cancer, after adjustment for other causes of death. Expected survival was derived from a life table that contained the probabilities of death or the central death rates for the general population in Malaysia, by single age, sex, and calendar year between 1993 and 2012. These life tables were obtained from the National Statistics Departments in Malaysia.

Given that the breast cancer patients in this setting tended to be younger, their RSRs were adjusted for age using the standard cancer population 1 (Corazziari et al, 2004) to enable international comparisons. The age-adjusted relative survival of patients in this study was subsequently compared with their counterparts diagnosed with stage I breast cancer during the same calendar period from several affluent settings (Walters et al, 2013). 


\section{RESULTS}

Median age at diagnosis was 51 years with an inter-quartile range of $44-60$ years. The majority of patients were married $(\sim 86 \%)$, and approximately half were postmenopausal at diagnosis (Table 1).

Breast cancer stage at presentation. In this study, 1155 women presented with stage I (23.4\%), 1926 with stage II (39.1\%), 1278 with stage III (25.9\%), and 571 with stage IV (11.6\%) breast cancer at diagnosis. The proportion of patients presenting with very early breast cancer (stage I) in UMMC substantially increased over time; $15.2 \%$ between 1993 and $1997,21.5 \%$ in $1998-2002,24.8 \%$ in 2003-2007, and 25.2\% in 2008-2011 $(P<0.001)$. Between 2000 and $2007, \sim 24 \%$ of our patients presented with stage I disease.

During the entire study period, only 176 patients with stage 0 (carcinoma in situ) were seen in UMMC; comprising 2.2\% of total breast cancers seen between 1993 and 1997, 2.8\% in 1998-2002, $3.2 \%$ in $2003-2007$, and $4.4 \%$ in $2008-2011$.

Factors influencing very early breast cancer presentation. Very early presentation was significantly associated with Chinese ethnicity, having one or two children, positive family history of breast cancer, and recent calendar periods of diagnosis (Table 1). Age at diagnosis, marital status, and menopausal status were not associated with stage at presentation. Stepwise backward logistic regression showed that only ethnicity, family history of breast cancer, and period of diagnosis were significantly and independently associated with very early presentation (Table 1).

Tumour characteristics. The median tumour size at presentation in patients with stage I breast cancer was $1.5 \mathrm{~cm}$, with an interquartile range of $0.8-2.0 \mathrm{~cm}$ (Table 2). Most patients presented with grade 2 tumours (55.0\%) followed by grade $3(26.4 \%)$ and grade $1(18.6 \%)$ tumours. Lymphovascular invasion was present in $28 \%$. Oestrogen receptor was positive in $70 \%$ of patients, whereas progesterone receptor was positive in $62 \%$ of patients. About $26 \%$ of patients had HER2-positive tumours.

Treatment patterns. Among patients subjected to surgery, $52.9 \%$ received mastectomy, whereas $47.1 \%$ underwent BCS (Table 2). Patients receiving mastectomy were more likely to be older, postmenopausal, of Chinese ethnicity, having three or more children, diagnosed in the most recent period, and have

Table 1. Factors associated with very early presentation of breast cancer in a setting without organised screening

\begin{tabular}{|c|c|c|c|c|c|}
\hline Characteristics & $\begin{array}{c}\text { Overall } \\
(N=4930)\end{array}$ & $\begin{array}{l}\text { Very early } \\
\text { presentation } \\
\text { (stage I) }^{a} \\
n=1155\end{array}$ & $\begin{array}{c}\text { More advanced } \\
\text { presentation } \\
\text { (stage II-IV) }^{\mathrm{b}} \\
n=3775\end{array}$ & $\begin{array}{l}\text { Univariable } \\
\text { odds ratio } \\
\text { for very early } \\
\text { presentation } \\
(95 \% \mathrm{Cl})\end{array}$ & $\begin{array}{l}\text { Multivariable } \\
\text { odds ratio } \\
\text { for very early } \\
\text { presentation } \\
(95 \% \mathrm{Cl})\end{array}$ \\
\hline \multicolumn{6}{|l|}{ Age, $n$ (\%) } \\
\hline $\begin{array}{l}<50 \text { years } \\
50-64 \text { years } \\
\geqslant 65 \text { years }\end{array}$ & $\begin{array}{r}2177(100.0) \\
1961(100.0) \\
792(100.0)\end{array}$ & $\begin{array}{l}494(22.7) \\
469(23.9) \\
192(24.2)\end{array}$ & $\begin{array}{r}1683(77.3) \\
1492(76.1) \\
600(75.8)\end{array}$ & $\begin{array}{c}1.00 \\
1.07(0.93-1.24) \\
1.09(0.90-1.32)\end{array}$ & $\begin{array}{l}- \\
- \\
-\end{array}$ \\
\hline \multicolumn{6}{|l|}{ Race, $n(\%)$} \\
\hline $\begin{array}{l}\text { Chinese } \\
\text { Malay } \\
\text { Indian } \\
\text { Others }\end{array}$ & $\begin{array}{r}3179(100.0) \\
1054(100.0) \\
615(100.0) \\
82(100.0) \\
\end{array}$ & $\begin{array}{r}852(26.8) \\
166(15.7) \\
112(18.2) \\
25(30.4) \\
\end{array}$ & $\begin{array}{r}2327(73.2) \\
888(84.3) \\
503(81.8) \\
57(69.6)\end{array}$ & \begin{tabular}{l}
\multicolumn{1}{c}{1.00} \\
$0.51(0.43-0.61)^{d}$ \\
$0.61(0.49-0.76)^{d}$ \\
$1.20(0.74-1.93)$
\end{tabular} & $\begin{array}{c}1.00 \\
0.52(0.43-0.63)^{d} \\
0.62(0.50-0.77)^{d} \\
1.21(0.75-1.95)\end{array}$ \\
\hline \multicolumn{6}{|l|}{ Parity, n (\%) } \\
\hline $\begin{array}{l}\text { Nulliparous } \\
1-2 \text { children } \\
\geqslant 3 \text { children } \\
\text { Unknown }\end{array}$ & $\begin{array}{c}788(100.0) \\
1313(100.0) \\
2134(100.0) \\
695\end{array}$ & $\begin{array}{c}182(23.1) \\
341(26.0) \\
473(22.2) \\
159\end{array}$ & $\begin{array}{c}606(76.9) \\
972(74.0) \\
1661(77.8) \\
536\end{array}$ & $\begin{array}{c}1.00 \\
1.17(0.95-1.44) \\
1.04(0.85-1.27)\end{array}$ & $\begin{array}{l}- \\
- \\
-\end{array}$ \\
\hline \multicolumn{6}{|c|}{ Family history ${ }^{\mathbf{e}}, \mathrm{n}(\%)$} \\
\hline $\begin{array}{l}\text { Yes } \\
\text { No } \\
\text { Missing }\end{array}$ & $\begin{array}{c}779(100.0) \\
3649(100.0) \\
502\end{array}$ & $\begin{array}{c}228(29.3) \\
820(22.5) \\
107\end{array}$ & $\begin{array}{r}551(70.7) \\
2829(77.5) \\
395 \\
\end{array}$ & $\begin{array}{c}1.43(1.20-1.70)^{d} \\
1.00\end{array}$ & $\begin{array}{c}1.37(1.15-1.63)^{\mathrm{d}} \\
1.00\end{array}$ \\
\hline \multicolumn{6}{|c|}{ Year of diagnosis, $n(\%)$} \\
\hline $\begin{array}{l}1993-1997 \\
1998-2002 \\
2003-2007 \\
2008-2011 \\
\text { Unknown } \\
\end{array}$ & $\begin{array}{r}448(100.0) \\
985(100.0) \\
1678(100.0) \\
1811(100.0) \\
8 \\
\end{array}$ & $\begin{array}{r}68(15.2) \\
212(21.5) \\
416(24.8) \\
457(25.2) \\
2 \\
\end{array}$ & $\begin{array}{c}380(84.8) \\
773(78.5) \\
1262(75.2) \\
1354(74.8) \\
6 \\
\end{array}$ & $\begin{array}{c}1.00 \\
1.51(1.09-2.09)^{d} \\
1.82(1.37-2.42)^{d} \\
2.00(1.50-2.64)^{d}\end{array}$ & $\begin{array}{c}1.00 \\
1.54(1.13-2.11)^{d} \\
1.79(1.35-2.38)^{d} \\
1.80(1.36-2.38)^{d}\end{array}$ \\
\hline \multicolumn{6}{|c|}{ 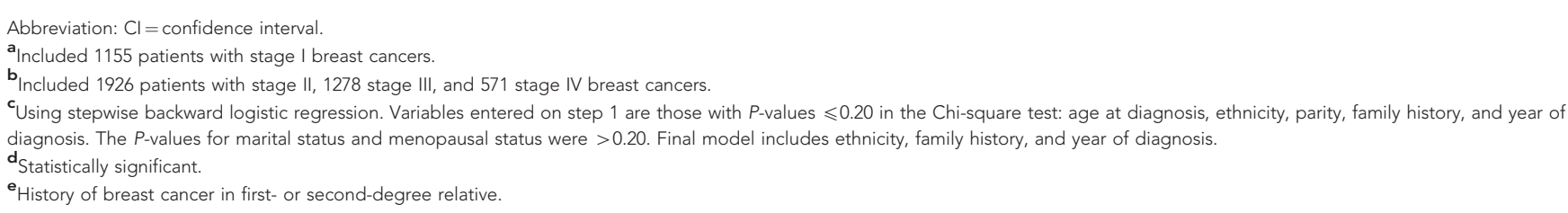 } \\
\hline
\end{tabular}


Table 2. Tumour characteristics and treatment patterns of patients with stage I breast cancer

\begin{tabular}{|l|c|}
\hline Tumour characteristics/treatment patterns $^{\mathbf{a}}$ & $\mathbf{N}, \%$ \\
\hline Size, median in cm & $1.5(0.8,2.0)^{\mathbf{b}}$ \\
\hline Grade & \\
\hline Well differentiated & $165(18.6)$ \\
Moderately differentiated & $488(55.0)$ \\
Poorly differentiated & $235(26.4)$ \\
Unknown & 267 \\
\hline Oestrogen receptor status & \\
\hline Positive & $765(69.9)$ \\
Negative & $329(30.1)$ \\
Unknown & 61 \\
\hline
\end{tabular}

\section{Progesterone receptor status}

\begin{tabular}{|l|c|}
\hline Positive & $587(62.0)$ \\
Negative & $360(38.0)$ \\
Unknown & 208
\end{tabular}

\section{HER2 status}

\begin{tabular}{|l|c|}
\hline Positive & $259(26.3)$ \\
Negative & $725(73.7)$ \\
Unknown & 171 \\
\hline Lymphovascular invasion & $254(27.9)$ \\
\hline Present & $658(72.1)$ \\
Absent & 243 \\
Unknown & \\
\hline
\end{tabular}

\section{Surgery}

\begin{tabular}{|l|c|}
\hline No surgery & $37(3.2)$ \\
Breast conserving surgery & $527(45.6)$ \\
Mastectomy & $591(51.2)$
\end{tabular}

\section{Radiotherapy ${ }^{c}$}

\begin{tabular}{l|c} 
Yes & $459(92.5)$ \\
No & $37(7.5)$ \\
Unknown & 31
\end{tabular}

\section{Endocrine therapy ${ }^{\mathrm{d}}$}

\begin{tabular}{|l|c|}
\hline Yes & $701(95.4)$ \\
No & $34(4.6)$ \\
Unknown & 30 \\
\hline
\end{tabular}

\section{Chemotherapy}

\begin{tabular}{l|l}
\hline Yes & $402(35.6)$ \\
No & $727(64.4)$
\end{tabular}

Unknown

\section{Chemotherapy regime}

First generation
Second generation
Third generation
Unknown

\section{$30(8.8)$}

$290(85.6)$

$19(5.6)$

63

$63-2$

Abbreviation: HER2 = Human Epidermal Growth Factor Receptor 2.

Included 1155 patients with stage I breast cancer.

Included patients receiving breast conserving surgery only.

Included patients receiving chemotherapy only. larger tumours. Following multivariable logistic regression, only age at diagnosis, postmenopausal status, Chinese ethnicity, and tumour size were independently and significantly associated with mastectomy (Table 3).

Overall, radiotherapy was administered in $50 \%$ of the patients. A vast majority of patients subjected to BCS in the present study had received adjuvant radiotherapy (92.5\%).

Among 765 patients with positive ER status in the current study, 701 have received endocrine therapy (95.4\%). Chemotherapy was administered in $36 \%$ of patients with stage I breast cancer. A majority of patients receiving chemotherapy were given second-generation regimes (fluorouracil, epirubicin, and cyclophosphamide), whereas the use of third generation (taxane-based) regimes was low. Of 615 women with node-negative breast cancers measuring $>1 \mathrm{~cm}, 259$ had received chemotherapy (42\%), irrespective of their hormone receptor status. Chemotherapy administration was independently associated with younger age at diagnosis, larger tumour size, higher tumour grades, the presence of LVI, ER-negative, and PR-negative status (Table 4).

Survival. The 5-year crude and age-adjusted relative survival of patients with stage I breast cancer in the current study were $97.8 \%$ (95\% CI: 95.6-99.6\%) and 99.1\% (95\% CI: 97.6-99.6\%) respectively.

In women diagnosed with stage I breast cancer between the year 2000 and 2007, the 3-year age-adjusted relative survival was $99.5 \%$, 95\% CI: 97.5-99.9\%.

\section{DISCUSSION}

An increasing number of women with breast cancer in this Malaysian setting are presenting very early despite the absence of an organised breast cancer screening program. Factors associated with very early presentation are Chinese ethnicity, a positive family history of breast cancer, and recent calendar period of diagnosis. More than half of the patients with stage I breast cancer in the current study received mastectomy, in particular those who were older at diagnosis, postmenopausal, of Chinese ethnicity, and having larger tumours. The 5-year age-adjusted relative survival of patients with very early breast cancer in the current study is very high (99.1\%, 95\% CI: 97.6-99.6\%).

Clinical breast examination by a trained health-care professional had been offered to Malaysian women aged 20-65 years attending primary health-care services since 2009. At the same time, women are taught the technique of BSE. Women who screen positive by $\mathrm{CBE}$ are referred for diagnostic mammography and other investigations and management at an appropriate facility. Since 2012, a targeted mammographic screening programme for women at high risk of breast cancer, that is, strong family history or known breast abnormalities, had been made available.

A recent study by the International Cancer Benchmarking Partnership Working Group had compared invasive breast cancer presentation by stage between several affluent western countries. Between the year 2000 and 2007, it was found that the proportion of stage I breast cancer was $41 \%$ in Canada, 29\% in Denmark, $43 \%$ in Norway, $45 \%$ in Sweden, and 40\% in United Kingdom (Walters et al, 2013). Analysis within the same period in the current study showed that $\sim 24 \%$ of patients presented with stage I disease. It is not surprising that the proportion of patients presenting at very early stages in the current study setting is much lower compared to above settings with organised screening mammography programme. However, the proportion of stage I breast cancer patients diagnosed before 2007 in this study ( 24\%) is somewhat closer to the estimates of $29 \%$ in Denmark, where nation-wide breast cancer screening only started in 2007 (Walters et al, 2013). In this Malaysian setting where screening for breast cancer is 
Table 3. Factors associated with mastectomy in patients with very early breast cancer ${ }^{\mathrm{a}}$

\begin{tabular}{|c|c|c|c|c|}
\hline Characteristics & $\begin{array}{l}\text { Mastectomy } \\
\quad(n=591)\end{array}$ & $\begin{array}{c}\text { Breast conserving } \\
\text { surgery } \\
(n=527)\end{array}$ & $\begin{array}{l}\text { Univariable odds ratio for } \\
\text { mastectomy } \\
(95 \% \mathrm{Cl})\end{array}$ & $\begin{array}{l}\text { Multivariable odds ratio for } \\
\text { mastectomy }{ }^{\mathrm{b}} \\
(95 \% \mathrm{Cl})\end{array}$ \\
\hline Age, in years, median ${ }^{c}$ & $55(48,64)$ & $49(43,56)$ & $1.05(1.04-1.06)^{d}$ & $1.02(1.01-1.04)^{d}$ \\
\hline \multicolumn{5}{|l|}{ Race, n (\%) } \\
\hline $\begin{array}{l}\text { Chinese } \\
\text { Malay } \\
\text { Indian } \\
\text { Others }\end{array}$ & $\begin{array}{r}476(57.6) \\
56(35.9) \\
51(45.9) \\
8(32.0)\end{array}$ & $\begin{array}{r}350(42.4) \\
100(64.1) \\
60(54.1) \\
17(68.0) \\
\end{array}$ & $\begin{array}{c}1.00 \\
0.41(0.29-0.59)^{d} \\
0.63(0.42-0.93)^{d} \\
0.35(0.15-0.81)^{d}\end{array}$ & $\begin{array}{c}1.00 \\
0.41(0.27-0.62)^{d} \\
0.55(0.35-0.87)^{d} \\
0.54(0.21-1.40)\end{array}$ \\
\hline \multicolumn{5}{|l|}{ Marital status, $n(\%)$} \\
\hline $\begin{array}{l}\text { Married } \\
\text { Not married } \\
\text { Not known }\end{array}$ & $\begin{array}{c}491(54.3) \\
70(47.6) \\
30\end{array}$ & $\begin{array}{c}414(45.7) \\
77(52.4) \\
36\end{array}$ & $\begin{array}{c}1.31(0.92-1.85) \\
1.00\end{array}$ & $\begin{array}{l}- \\
- \\
-\end{array}$ \\
\hline \multicolumn{5}{|l|}{ Parity, n (\%) } \\
\hline $\begin{array}{l}\text { Nulliparous } \\
1-2 \text { children } \\
\geqslant 3 \text { children } \\
\text { Unknown }\end{array}$ & $\begin{array}{c}86(48.9) \\
162(48.5) \\
283(60.4) \\
60\end{array}$ & $\begin{array}{c}90(51.1) \\
172(51.5) \\
175(39.6) \\
90\end{array}$ & $\begin{array}{c}1.00 \\
0.99(0.68-1.42) \\
1.69(1.19-2.40)^{d}\end{array}$ & $\begin{array}{c}1.00 \\
0.77(0.51-1.18) \\
1.32(0.87-2.00)\end{array}$ \\
\hline \multicolumn{5}{|l|}{ Menopausal status, n (\%) } \\
\hline $\begin{array}{l}\text { Premenopausal } \\
\text { Postmenopausal } \\
\text { Unknown }\end{array}$ & $\begin{array}{c}198(39.6) \\
355(63.7) \\
38\end{array}$ & $\begin{array}{c}302(60.4) \\
202(36.3) \\
23\end{array}$ & $\begin{array}{c}1.00 \\
2.68(2.09-3.44)^{d}\end{array}$ & $\begin{array}{c}1.00 \\
1.96(1.27-3.02)^{d}\end{array}$ \\
\hline \multicolumn{5}{|l|}{ Year of diagnosis, $n$ (\%) } \\
\hline $\begin{array}{l}1993-1997 \\
1998-2002 \\
2003-2007 \\
2008-2011 \\
\text { Unknown }\end{array}$ & $\begin{array}{c}37(55.2) \\
89(43.8) \\
215(53.3) \\
248(56.0) \\
2\end{array}$ & $\begin{array}{c}30(44.8) \\
114(56.2) \\
188(46.7) \\
195(44.0) \\
0\end{array}$ & $\begin{array}{c}1.00 \\
0.63(0.36-1.10) \\
0.93(0.55-1.56) \\
1.03(0.62-1.73)\end{array}$ & $\begin{array}{l}- \\
- \\
- \\
-\end{array}$ \\
\hline Tumour size, in $\mathrm{cm}$, median $^{\mathrm{c}}$ & $1.5(1.0,2.0)$ & $1.4(0.8,1.7)$ & $1.21(1.02-1.45)^{d}$ & $1.22(1.01-1.48)^{d}$ \\
\hline \multicolumn{5}{|l|}{ Lymphovascular invasion } \\
\hline $\begin{array}{l}\text { Present } \\
\text { Absent } \\
\text { Unknown }\end{array}$ & $\begin{array}{c}144(57.4) \\
338(52.4) \\
109 \\
\end{array}$ & $\begin{array}{c}107(42.6) \\
307(47.6) \\
113 \\
\end{array}$ & $\begin{array}{c}1.22(0.91-1.64) \\
1.00\end{array}$ & \\
\hline \multicolumn{5}{|c|}{ 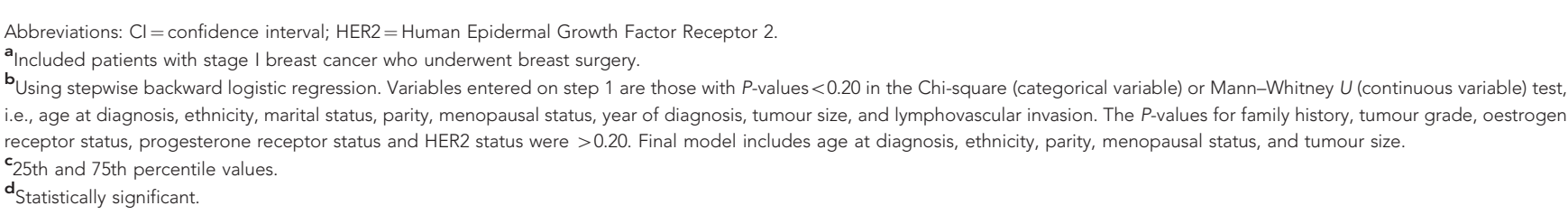 } \\
\hline
\end{tabular}

opportunistic, it was found that the proportion of patients with carcinoma in situ was extremely small. The increasing trend towards very early presentation observed in the current study hence largely reflects improved breast health literacy in the background population.

Ethnicity affects stage at breast cancer presentation in the United States, as well as in multiethnic Asian settings (Bhoo-Pathy et al, 2012). While socio-economic disparities between the ethnic groups may confound this association (Brawley, 2002), some argue that individuals of a particular ethnic group may share certain beliefs, attitudes, and behaviours (culture), thus impacting their health practices, and resulting in similar illness profiles within that ethnic group (Lannin et al, 1998). A recent study in Malaysia showed that a higher proportion of Chinese women had good knowledge of breast cancer as compared with Malay and Indian women (Hadi et al, 2010). This may partly explain the association between Chinese ethnicity and very early breast cancer presentation in the current study. The positive association between family history of breast cancer and very early presentation seems to support the notion that women with affected family members are more likely to have higher breast cancer awareness and therefore, are more ready to engage in preventive and screening activities (Verkooijen et al, 2009). As expected, it was also observed that very early stage at presentation was more common in recent years, which could be due to a combination of improved socio-economic and education status, as well as implementation of health education, and early detection programmes (Devi et al, 2007; Dahlui et al, 2012). While it has been suggested that married women are more likely to present with earlier stages of breast cancer due to increased social support and social networks (Osborne et al, 2005), this was not apparent in this study, probably due to low numbers of unmarried patients. 
Table 4. Factors associated with chemotherapy in patients with very early breast cancer ${ }^{\mathrm{a}}$

\begin{tabular}{|c|c|c|c|c|}
\hline Characteristics & $\begin{array}{l}\text { Chemotherapy } \\
\qquad(n=402)\end{array}$ & $\begin{array}{l}\text { No chemotherapy } \\
(n=727)\end{array}$ & $\begin{array}{l}\text { Univariable odds ratio for } \\
\text { chemotherapy } \\
(95 \% \mathrm{Cl})\end{array}$ & $\begin{array}{l}\text { Multivariable odds ratio for } \\
\text { chemotherapy } \\
(95 \% \mathrm{Cl})\end{array}$ \\
\hline Age, in years, median ${ }^{c}$ & $47(41,54)$ & $55(48,64)$ & $0.93(0.92-0.95)^{d}$ & $0.91(0.90-0.93)^{d}$ \\
\hline \multicolumn{5}{|l|}{ Race, n (\%) } \\
\hline $\begin{array}{l}\text { Chinese } \\
\text { Malay } \\
\text { Indian } \\
\text { Others }\end{array}$ & $\begin{array}{r}285(34.3) \\
71(43.0) \\
37(33.6) \\
9(37.5)\end{array}$ & $\begin{array}{r}545(65.7) \\
94(57.0) \\
73(66.4) \\
15(62.5)\end{array}$ & $\begin{array}{c}1.00 \\
1.44(1.03-2.03)^{d} \\
0.97(0.64-1.48) \\
1.15(0.50-2.65)\end{array}$ & $\begin{array}{l}- \\
- \\
- \\
-\end{array}$ \\
\hline
\end{tabular}

Menopausal status, $n(\%)$

\begin{tabular}{|l|c|c|}
\hline Premenopausal & $242(47.9)$ & $263(52.1)$ \\
Postmenopausal & $134(23.8)$ & $428(76.2)$ \\
Unknown & 26 & 36 \\
\hline
\end{tabular}

Year of diagnosis, $n(\%)$

\begin{tabular}{|c|c|c|c|c|}
\hline 1993-1997 & $17(25.0)$ & $51(75.0)$ & $0.68(0.38-1.21)$ & $1.36(0.55-3.39)$ \\
\hline 1998-2002 & 72 (34.0) & $140(66.0)$ & $1.04(0.74-1.48)$ & $0.79(0.44-1.45)$ \\
\hline 2003-2007 & $167(40.9)$ & $241(59.1)$ & $1.41(1.06-1.86)^{d}$ & $1.82(1.20-2.76)^{d}$ \\
\hline 2008-2011 & $145(33.0)$ & $294(67.0)$ & 1.00 & 1.00 \\
\hline Unknown & 1 & 1 & & \\
\hline Tumour size, in $\mathrm{cm}$, median ${ }^{c}$ & $1.5(1.0,2.0)$ & $1.4(0.6,1.8)$ & $1.63(1.34-1.97)^{d}$ & $1.46(1.10-1.95)^{d}$ \\
\hline \multicolumn{5}{|l|}{ Grade, $n(\%)$} \\
\hline $\begin{array}{l}\text { Well differentiated } \\
\text { Moderately differentiated } \\
\text { Poorly differentiated } \\
\text { Unknown }\end{array}$ & $\begin{array}{c}18(11.0) \\
178(37.6) \\
166(73.5) \\
40\end{array}$ & $\begin{array}{c}145(89.0) \\
296(62.4) \\
60(26.5) \\
226\end{array}$ & $\begin{array}{c}0.05(0.03-0.08)^{d} \\
0.22(0.15-0.31)^{d} \\
1.00\end{array}$ & $\begin{array}{c}0.07(0.03-0.14)^{d} \\
0.30(0.19-0.48)^{d} \\
1.00\end{array}$ \\
\hline
\end{tabular}

Lymphovascular invasion, $n$ (\%)

\begin{tabular}{|l|c|c|c|c|}
\hline Present & $150(60.7)$ & $97(39.3)$ & $3.90(2.87-5.31)^{\mathbf{d}}$ & 1.00 \\
Absent & $183(28.4)$ & $462(71.6)$ & 1.00 & \\
Unknown & 69 & 168 & \\
\hline
\end{tabular}

Oestrogen receptor status, $n(\%)$

\begin{tabular}{|l|c|c|c|c}
\hline Positive & $197(26.3)$ & $553(73.7)$ & 1.00 & 1.00 \\
Negative & $194(61.0)$ & $124(39.0)$ & $4.39(3.33-5.80)^{\mathbf{d}}$ & $2.65(1.60-4.37)^{\mathbf{d}}$ \\
Unknown & 11 & 50 &
\end{tabular}

Progesterone receptor status, $\mathbf{n}(\%)$

\begin{tabular}{|c|c|c|c|c|}
\hline $\begin{array}{l}\text { Positive } \\
\text { Negative } \\
\text { Unknown }\end{array}$ & $\begin{array}{l}151(26.3) \\
192(55.3) \\
59\end{array}$ & $\begin{array}{l}423(73.7) \\
155(44.7) \\
149\end{array}$ & $\begin{array}{c}1.00 \\
3.47(2.62-4.60)^{d}\end{array}$ & $\begin{array}{c}1.00 \\
1.73(1.03-2.90)^{d}\end{array}$ \\
\hline \multicolumn{5}{|l|}{ HER2 status } \\
\hline $\begin{array}{l}\text { Positive } \\
\text { Negative } \\
\text { Unknown }\end{array}$ & $\begin{array}{c}113(34.6) \\
245(45.0) \\
44 \\
\end{array}$ & $\begin{array}{c}138(65.4) \\
463(55.0) \\
126 \\
\end{array}$ & $\begin{array}{c}1.55(1.16-2.01)^{d} \\
1.00\end{array}$ & - \\
\hline 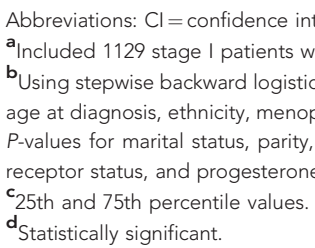 & $\begin{array}{l}\text { HER2 = Human } \\
\text { nemotherapy } \\
\text { sion. Variables } \\
\text { tatus, year of } \\
\text { mily history w } \\
\text { tor status. }\end{array}$ & $\begin{array}{l}\text { Srowth Factor } \\
\text { status were } \\
\text { step } 1 \text { are thos } \\
\text { nour size, grad } \\
\text { inal model inc }\end{array}$ & $\begin{array}{l}\text { in the Chi-square (cates } \\
\text { asion, oestrogen recep } \\
\text { is, menopausal status, }\end{array}$ & $\begin{array}{l}\text { Whitney U (continuous variable) test: } \\
\text { eceptor status, and HER2 status. The } \\
\text { lymphovascular invasion, oestrogen }\end{array}$ \\
\hline
\end{tabular}

In the current study, a large proportion of women underwent mastectomy. Following the NIH Consensus Development Conference in 1990, BCS became the preferred choice of surgery for women with early breast cancer in western settings (Lazovich et al, 1999). A recent study among primarily stage I breast cancer patients in the United States found that mastectomy rates were $38 \%$, compared with $53 \%$ in this study (Mahmood et al, 2013). The finding that older age at diagnosis is more likely to be associated with mastectomy is in stark contrast to the study conducted in the United States, whereby the preponderance for mastectomy was 
most pronounced in young patients (Mahmood et al, 2013). This difference may be driven by cultural factors in older Asian women who seem to accept mastectomy as a choice of therapy more readily, since almost all of them would have completed their families, breast fed their children, and are less concerned with their physical appearance (Wong et al, 2008; Gumus et al, 2010). However, in very affluent western settings, it may be that the young women are more likely to have undergone genetic testing, receive preoperative breast MRI (Mahmood et al, 2013), or offered immediate breast reconstruction (Greenberg et al, 2011), all of which are shown to be positively associated with mastectomy. In the current study, it is thought that postmenopausal women prefer mastectomy due to differences in their priority for sexuality and body image compared with their premenopausal counterparts. Chinese women were more likely to undergo mastectomy even after taking their age, menopausal status, and tumour sizes into account. This may be due to their smaller breast sizes compared with the Malays and the Indians, as well as fear of radiotherapy (Wong et al, 2008). The choice of mastectomy in Chinese women may also reflect their culturally driven inclination to be completely rid of breast cancer (Lee, 2002; Wong et al, 2008). The Chinese seem to view mastectomy as the best course of action to prevent recurrence and it was deemed to 'ensure a 100\% cure' compared with other treatment options (Wong et al, 2008).

While the NIH guideline recommends chemotherapy administration for all patients with node-negative breast cancer with tumour sizes measuring $>1 \mathrm{~cm}$ irrespective of hormone receptor status, only $42 \%$ of such patients in the current study received chemotherapy (Eifel et al, 2001). However, divergence between consensus recommendations and clinical practice had been reported even in affluent western practices, raising the question of whether the recommendations are overly aggressive, or whether the clinicians are too conservative in their use of chemotherapy (Lu et al, 2003). A study based on the New Mexico Tumour Registry for instance revealed that only $11 \%$ of its patients with stage I breast cancer received adjuvant chemotherapy (Lu et al, 2003). This is most probably due to the fact that a higher proportion of patients in the above study were 65 years and older compared with the current study making them less likely to receive adjuvant chemotherapy. The finding that increasing age is inversely associated with the use of chemotherapy, independent of hormone receptor status, complements previous study results (Lu et al, 2003; Sukel et al, 2008), and maybe attributed to decreasing efficacy of adjuvant chemotherapy with age, and perhaps concerns of increasing chemotherapy-related toxicity in older women (Early Breast Cancer Trialists' Collaborative Group, 1998). In this cohort of Asian women with node-negative breast cancer, chemotherapy administration is associated with larger tumour size, higher tumour grade, the presence of LVI, and the absence of ER expression, similar to western practices ( $\mathrm{Lu}$ et al, 2003; Sukel et al, 2008), and in line with the 2005 St Gallen Panel recommendation (Goldhirsch et al, 2005).

It appears that the survival of patients with stage I breast cancer in this study is similar to reported age-adjusted net survival rates in affluent western settings during the same calendar period (Walters et al, 2013). This reaffirms that very early presentation with breast cancer is associated with a high survival rate, be it in resourcelimited or affluent settings. Nevertheless, breast cancer is more common in women with higher socio-economic status, that is, higher levels of education and income (Clarke et al, 2002) making life expectancies between the patients and the background population not entirely comparable. Since data on socio-economic status were not available for matching both in the breast cancer registry and in the Malaysian life tables, it remains possible that (relative) survival may have been overestimated in the current study due to mismatch in the socio-economic status between the breast cancer patients and the background population in Malaysia (Howlader et al, 2010).
As this study was conducted in a tertiary referral centre with oncology services, it is possible that we may have underestimated the proportion of patients with stage I breast cancer. This is in view that a substantial number of patients with stage I breast cancer would have been subjected to locoregional management without being considered for adjuvant chemotherapy, and hence not referred to our centre. On the other hand, patients with more advanced stages of breast cancer would have been more likely to be referred. Given that UMMC serves a predominantly middleincome urban population where a majority of breast cancer patients are of Chinese ethnicity, whereas the Malays form the majority of Malaysian population, our findings may not necessarily reflect the overall situation of very early breast cancer presentation in Malaysia.

This study provides an estimate of increases in early breast cancer presentation, which is largely independent of mass screening effect. Even though it used a hospital-based breast cancer registry, this is the best estimate, which is currently available from a middle-income country without organised breast cancer screening.

In conclusion, presentation of very early breast cancers is on the rise in this Asian setting without organised breast cancer screening. Women presenting with stage I breast cancer in this study seem to experience high survival rates similar to their counterparts from affluent western settings.

\section{ACKNOWLEDGEMENTS}

This study was financially supported by the Ministry of Education, Malaysia (High Impact Research Grant [UM.C/HIR/MOHE/06]).

\section{CONFLICT OF INTEREST}

The authors declare no conflict of interest.

\section{REFERENCES}

Anderson BO, Cazap E, El Saghir NS, Yip CH, Khaled HM, Otero IV, Adebamowo CA, Badwe RA, Harford JB (2011) Optimisation of breast cancer management in low-resource and middle-resource countries: executive summary of the Breast Health Global Initiative consensus, 2010. Lancet Oncol 12: 387-398.

Bhoo-Pathy N, Hartman M, Yip CH, Saxena N, Taib NA, Lim SE, Iau P, Adami HO, Bulgiba AM, Lee SC, Verkooijen HM (2012) Ethnic differences in survival after breast cancer in South East Asia. PLoS One 7: e30995.

Bhoo Pathy N, Yip CH, Taib NA, Hartman M, Saxena N, Iau P, Bulgiba AM, Lee SC, Lim SE, Wong JE, Verkooijen HM (2011) Breast Cancer in Asian Women: results from the Singapore-Malaysia Hospital Based Breast Cancer Registry. Breast 20: S75-S80.

Brawley OW (2002) Disaggregating the effects or race and poverty on breast cancer outcomes. J Natl Cancer Inst 94: 471-473.

Clarke CA, Glaser SL, West DW, Ereman RR, Erdmann CA, Barlow JM, Wrensch MR (2002) Breast cancer incidence and mortality trends in an affluent population: Marin County, California, USA, 1990-1999. Breast Cancer Res 4: R13.

Coleman MP, Quaresma M, Berrino F, Lutz JM, De Angelis R, Capocaccia R, Baili P, Rachet B, Gatta G, Hakulinen T, Micheli A, Sant M, Weir HK, Elwood JM, Tsukuma H, Koifman S, E Silva GA, Francisci S, Santaquilani M, Verdecchia A, Storm HH, Young JL. CONCORD Working Group (2008) Cancer survival in five continents: a worldwide population-based study (CONCORD). Lancet Oncol 9: 730-756.

Corazziari I, Quinn M, Capocaccia R (2004) Standard cancer patient population for age standardising survival ratios. Eur J Cancer 40: 2307-2316. 
Dahlui M, Gan DEH, Taib NA, Pritam R, Lim J (2012) Predictors of breast cancer screening uptake: a pre-intervention community survey in Malaysia. Asian Pacific J Cancer Prev 13: 3443-3449.

Devi BC, Tang TS, Corbex M (2007) Reducing by half the percentage of latestage presentation for breast and cervix cancer over 4 years: a pilot study of clinical downstaging in Sarawak, Malaysia. Ann Oncol 18: 1172-1176.

Early Breast Cancer Trialists' Collaborative Group (1998) Polychemotherapy for early breast cancer: an overview of the randomised trials. Lancet 352: 930-942.

Eifel P, Axelson JA, Costa J, Crowley J, Curran Jr WJ, Deshler A, Fulton S, Hendricks CB, Kemeny M, Kornblith AB, Louis TA, Markman M, Mayer R, Roter D (2001) National Institutes of Health Consensus Development Conference Statement: adjuvant therapy for breast cancer, November 1-3, 2000. J Natl Cancer Inst 93: 979-989.

Fontenoy AM, Leux C, Delacour-Billon S, Allioux C, Frenel JS, Campone M, Molinié F (2010) Recent trends in breast cancer incidence rates in the Loire-Atlantique, France: a decline since 2003. Cancer Epidemiol 34: $238-243$.

Greenberg CC, Lipsitz SR, Hughes ME, Edge SB, Theriault R, Wilson JL, Carter WB, Blayney DW, Niland J, Weeks JC (2011) Institutional variation in the surgical treatment of breast cancer: a study of the NCCN. Ann Surg 254: 339-345.

Goldhirsch A, Glick JH, Gelber RD, Coates AS, Thürlimann B, Senn HJ. Panel members. Meeting highlights: International expert consensus on the primary therapy of early breast cancer. Ann Oncol (2005) 16: 1569-1583.

Gumus M, Ustaalioglu BO, Garip M, Kiziltan E, Bilici A, Seker M, Erkol B, Salepci T, Mayadagli A, Turhal NS (2010) Factors that affect patients' decision-making about mastectomy or breast conserving surgery, and the psychological effect of this choice on breast cancer patients. Breast Care (Basel) 5: 164-168.

Hadi MA, Hassali MA, Shafie AA, Awaisu A (2010) Knowledge and perception of breast cancer among women of various ethnic groups in the state of Penang: a cross-sectional survey. Med Princ Pract 19: 61-67.

Howlader N, Ries LAG, Mariotto AB, Reichman ME, Ruhl J, Cronin KA (2010) Improved estimates of cancer-specific survival rates from population-based data. J Natl Cancer Inst 102: 1584-1598.

Kang MH, Park EC, Choi KS, Suh M, Jun JK, Cho E (2013) The national cancer screening program for breast cancer in the republic of Korea: is it cost-effective? Asian Pac J Cancer Prev 14: 2059-2065.

Kwong A, Cheung PS, Wong AY, Hung GT, Lo G, Tsao M, Chan EW, Wong T, Ma M (2008) The acceptance and feasibility of breast cancer screening in the East. The Breast 17: 44-52.

Lannin DR, Mathews HF, Mitchell J, Swanson MS, Swanson FH, Edwards MS (1998) Influence of socioeconomic and cultural factors on racial differences in late-stage presentation of breast cancer. JAMA 279: 1801-1807.

Lazovich D, Solomon CC, Thomas DB, Moe RE, White E (1999) Breast conservation therapy in the United States following the 1990 National Institutes of Health Consensus Development Conference on the treatment of patients with early stage invasive breast carcinoma. Cancer 86: 628-637.

Lee MM (2002) Breast cancer in Asian women. West J Med 176: 91-92.

Lim SM, Lee HY, Choi KS, Jun JK, Park EC, Kim Y, Han MA, Oh DK, Shim JI (2010) Trends of mammography use in a National Breast Cancer Screening Program, 2004-2008. Cancer Res Treat 42: 199-202.

Lu X, Key CR, Osborne C, Mahnken JD, Goodwin JS (2003) Discrepancy between consensus recommendations and actual community use of adjuvant chemotherapy in women with breast cancer. Ann Intern Med 138: 90-97.
Mahmood U, Hanlon AL, Koshy M, Buras R, Chumsri S, Tkaczuk KH, Cheston SB, Regine WF, Feigenberg SJ (2013) Increasing national mastectomy rates for the treatment of early stage breast cancer. Ann Surg Oncol 20: 1436-1443.

National Institutes of Health (1990) Treatment of Early-Stage Breast Cancer. NIH Consensus Statement Online 8: 1-19. Available at: http://consensus.nih.gov/1990/1990earlystagebreastcancer081html.htm (accessed on 5th October 2013).

Okonkwo QL, Draisma G, der Kinderen A, Brown ML, de Koning HJ (2008) Breast cancer screening policies in developing countries: a cost effectiveness analysis for India. J Natl Cancer Inst 100: 1290-1300.

Osborne C, Ostir GV, Du X, Peek MK, Goodwin JS (2005) The influence of marital status on the stage at diagnosis, treatment, and survival of older women with breast cancer. Breast Cancer Res Treat 93: 41-47.

Owen D, Tyldesley S, Alexander C, Speers C, Truong P, Nichol A, Wai ES (2013) Outcomes in patients treated with mastectomy for ductal carcinoma in situ. Int J Radiat Oncol Biol Phys 85: 129-134.

Porter P (2008) "Westernizing" women's risks? Breast cancer in lower-income countries. N Engl J Med 358: 213-216.

Ravdin PM, Cronin KA, Berg CD, Howlader N, Chlebowski RT, Feuer EJ, Edwards BK, Berry DA (2007) The decrease in breast cancer incidence in 2003 in the United States. N Eng J Med 356: 1670-1674.

Ries LAG, Eisner MP (2013) National Cancer Institute. SEER Survival Monograph. Chapter 13. Cancer of the Female Breast. Available at: http://seer.cancer.gov/publications/survival/surv_breast.pdf (accessed on 13th August 2013).

Sukel MP, van de Poll-Franse LV, Nieuwenhuijzen GA, Vreugdenhil G, Herings RM, Coebergh JW, Voogd AC (2008) Substantial increase in the use of adjuvant systemic treatment for early stage breast cancer reflects changes in guidelines in the period 1990-2006 in the southeastern Netherlands. Eur J Cancer 44: 1846-1854.

Verkooijen HM, Rapiti E, Fioretta G, Vinh-Hung V, Keller J, Benhamou S, Vlastos G, Chappuis PO, Bouchardy C (2009) Impact of a positive family history on diagnosis, management, and survival of breast cancer: different effects across socio-economic groups. Cancer Causes Control 20: 1689-1696.

Walters S, Maringe C, Butler J, Rachet B, Barrett-Lee P, Bergh J, Boyages J, Christiansen P, Lee M, Wärnberg F, Allemani C, Engholm G, Fornander T, Gjerstorff ML, Johannesen TB, Lawrence G, McGahan CE, Middleton R, Steward J, Tracey E, Turner D, Richards MA, Coleman MP. ICBP Module 1 Working Group (2013) Breast cancer survival and stage at diagnosis in Australia, Canada, Denmark, Norway, Sweden and the UK, 2000-2007: a population-based study. Br J Cancer 108: 1195-1208.

Wang PP, Cao Y (1996) Incidence trends of female breast cancer in Saskatchewan, 1932-1990. Breast Cancer Res Treat 37: 197-207.

Wong ST, Chen W, Bottorf JL, Hislop TG (2008) Treatment decision making among Chinese women with DCIS. J Psychosoc Oncol 26: $53-73$.

Woo PPS, Kim JJ, Leung GM (2007) What is the most cost-effective population-based cancer screening program for Chinese women? J Clin Oncol 25: 617-624.

This work is published under the standard license to publish agreement. After 12 months the work will become freely available and the license terms will switch to a Creative Commons AttributionNonCommercial-Share Alike 3.0 Unported License. 